\title{
IRRIGATION FREQUENCY ON ECONOMIC PERFORMANCE AND PRODUCTIVITY OF TOMATO IN THE COAST OF CEARÁ, BRAZIL ${ }^{1}$
}

\author{
MARIO DE OLIVEIRA REBOUÇAS NETO ${ }^{2 *}$, BENITO MOREIRA DE AZEVEDO ${ }^{3}$, THALES VINÍCIUS VIANA DE \\ ARAÚJO $^{3}$, DENISE VIEIRA DE VASCONCELOS ${ }^{3}$, CARLOS NEWDMAR VIEIRA FERNANDES $^{4}$
}

\begin{abstract}
The objective of this work was to technically and economically evaluate the productivity of tomato grown under different irrigation frequencies in the coast of Ceará, Brazil. The experiment was conducted in the experimental area of the Federal University of Ceará, Fortaleza, State of Ceará, Brazil, from August to December of 2011 and 2012. A randomized block experimental design was used in the two crop cycles, with six irrigation frequencies, consisted of 2 (F2), 3 (F3), 4 (F4), 5 (F5), 6 (F6) and 7 (F7) days of interval between irrigations, and four replications. The treatments were evaluated at twenty days after transplanting (DAT), when the plants were fully acclimated to the field. The harvesting began at seventy DAT and ended at ninety DAT. The variables analyzed were fruit length, diameter and weight, number of fruits per plant and fruit yield. The economic performance of the crop was also evaluated. Tomato producers of the coastal region of the State of Ceará, who aim to increase economic return, i.e., net income, must adopt a twoday irrigation frequency (F2).
\end{abstract}

Keywords: Lycorpersicum esculentum. Irrigation management. Production.

\section{FREQUENCIA DE IRRIGAÇÃO NO DESEMPENHO ECONÔMICO E PRODUTIVO DO TOMATEIRO NO LITORAL CEARENSE}

\begin{abstract}
RESUMO - Objetivou-se, com esse trabalho, a avaliação técnica e econômica da produtividade do tomateiro cultivado com diferentes frequências de irrigação no litoral cearense. $\mathrm{O}$ experimento foi conduzido em campo na área experimental da Universidade Federal do Ceará, Fortaleza, Ceará, durante o período de agosto a dezembro nos anos de 2011 e de 2012. O delineamento experimental utilizado nos dois ciclos de avaliações foi de blocos ao acaso, composto de seis tratamentos equivalentes às frequências de irrigação: F2 (dois dias); F3 (três dias); F4 (quatro dias), F5 (cinco dias), F6 (seis dias) e F7 (sete dias), com quatro repetições. Aos vinte dias após o transplantio (DAT), quando as plantas já estavam aclimatizadas no campo, foram diferenciados os tratamentos. A colheita se iniciou aos setenta DAT e foi concluída aos noventa DAT. Foram analisadas as seguintes variáveis: comprimento, diâmetro e massa do fruto, número de frutos por planta e a produtividade, sendo também realizada a análise econômica do cultivo. Os produtores da região litorânea do estado do Ceará, que visem um maior rendimento econômico quanto a receita liquida devem adotar uma Frequência de irrigação de dois dias (F2).
\end{abstract}

Palavras-chave: Lycorpersicum esculentum. Manejo de irrigação. Produção.

${ }^{1}$ Received for publication in 06/03/2016; accepted in 02/01/2017.

Paper extracted from the first author's doctoral thesis, financed by $\mathrm{CNPq}$.

${ }^{2}$ Instituto Federal do Piauí, Campo Maior, PI, Brazil; agromario@gmail.com.

${ }^{3}$ Department of Agricultural Engineering, Universidade Federal do Ceará, Fortaleza, CE, Brazil; benito@ufc.br, thales@ufc.br, denisevasconcelos@hotmail.com.

${ }^{4}$ Instituto Federal do Ceará, Iguatu, CE, Brazil; newdmar@gmail.com.
} 


\section{INTRODUCTION}

Tomato (Lycopersicum esculentum Mill.) is originally from the Andean region, Ecuador to northern Chile (HIGUTI et al. 2010). It is the second most important vegetable grown in Brazil (RONCHI et al., 2010). The tomato production in the Northeast of Brazil was 611.7 thousand $\mathrm{Mg}$, and the state of Ceará had the Northeast third largest production (114.5 thousand $\mathrm{Mg}$ ), with a planted area of 2.2 thousand hectares, in 2013 (IBGE, 2013).

Water is scarce in the Northeast of Brazil, and rainfall distribution throughout the year does not adequately supply the water needs of crops in most of its states, affecting the growth and development of plants (FAGAN et al., 2009).

Thus, irrigation management for vegetables is needed, meaning to define the irrigation type, amount and timing, aiming to increase productivity and quality of plants and maximize water use efficiency (MAROUELLI; SILVA; SILVA, 2008).

Proper management of nutrition, supplying of water, use of improved cultivars and phytosanitary measures are required to obtain high fruit yields and consequently, economic returns with tomato crops (SILVA et al., 2013). The supplying of water is one of the main of these factors due to its great effect on growth, development and production characteristics of tomato (SANTANA; VIEIRA; BARRETO, 2009). Thus, irrigation increases productivity and improve fruit quality, which may result in better prices in the market (LIMA JÚNIOR et al., 2011).

The required irrigation frequency by crops depends on the local climate, amount of water that can be stored in the soil after irrigation (BERNARDO; SOARES; MANTOVANI, 2009), effective depth of the plant root system and soil area covered (SEPASKHAH; AHMADI, 2010).

Researches have shown the effects of carefully managed irrigations, presenting their contributions to increase yield of several vegetables and improve product quality (CARVALHO et al., 2011; SILVA et al., 2014).

In this context, the objective of this work was to technically and economically evaluate the productivity of tomato grown under different irrigation frequencies in the coast of Ceará, Brazil.

\section{MATERIAL AND METHODS}

Field experiments were conducted from August to December of 2011 and 2012 in the experimental area of the Agrometeorological Station of the Federal University of Ceará (UFC), Fortaleza, State of Ceará (CE), Brazil ( $3^{\circ} 44^{\prime} 45^{\prime \prime} \mathrm{S}, 38^{\circ} 34^{\prime} 55^{\prime \prime} \mathrm{W}$ and $20 \mathrm{~m}$ of altitude). According to the classification of Köppen, the climate of the region is type Aw', tropical rainy. The monthly data of the climatic variables collected during the experiments are shown in Table 1.

Table 1. Monthly data of the climatic variables during the conduction of the experiments.

\begin{tabular}{|c|c|c|c|c|c|c|c|c|c|c|}
\hline \multirow[t]{2}{*}{ Month } & \multicolumn{2}{|c|}{$\begin{array}{c}\text { Air Average } \\
\text { Temperature }\left({ }^{\circ} \mathrm{C}\right)\end{array}$} & \multicolumn{2}{|c|}{ Precipitation $(\mathrm{mm})$} & \multicolumn{2}{|c|}{$\begin{array}{c}\text { Relative } \\
\text { Humidity (\%) }\end{array}$} & \multicolumn{2}{|c|}{$\begin{array}{l}\text { Wind average } \\
\text { speed }\left(\mathrm{m} \mathrm{s}^{-1}\right)\end{array}$} & \multicolumn{2}{|c|}{$\begin{array}{l}\text { Solar Radiation } \\
\left(\mathrm{MJ} . \mathrm{m}^{-2} \text { month }^{-1}\right)\end{array}$} \\
\hline & 2011 & 2012 & 2011 & 2012 & 2011 & 2012 & 2011 & 2012 & 2011 & 2012 \\
\hline August & 26.6 & 28.7 & 51.0 & 0.0 & 71 & 73 & 4.1 & 3.5 & 381.6 & 333.8 \\
\hline September & 27.0 & 28.8 & 0.0 & 0.0 & 67 & 73 & 4.5 & 4.0 & 517.9 & 289.0 \\
\hline October & 27.1 & 28.9 & 23.8 & 2.3 & 72 & 73 & 4.2 & 4.4 & 540.1 & 203.5 \\
\hline November & 27.4 & 29.3 & 7.3 & 0.5 & 73 & 73 & 3.8 & 4.0 & 302.3 & 442.5 \\
\hline December & 27.7 & 29.7 & 6.7 & 1.8 & 71 & 74 & 3.7 & 3.8 & 251.1 & 465.1 \\
\hline
\end{tabular}

Source: Agrometeorological Station of the Federal University of Ceará.

The soil of the experimental area was classified as Red-Yellow Argissolo of sandy-loam texture (EMBRAPA, 2006). Composite soil samples were collected from the layer $0.0-0.2 \mathrm{~m}$ before the implementation of the experiments. The soil presented mean field capacity of $7.52\left(\mathrm{~g} 100 \mathrm{~g}^{-1}\right)$, mean permanent wilt point of $4.52\left(\mathrm{~g} 100 \mathrm{~g}^{-1}\right)$, specific mass of $1.43 \mathrm{~g} \mathrm{~cm}^{-3}, 113 \mathrm{~g} \mathrm{~kg}^{-1}$ of clay, $96 \mathrm{~g} \mathrm{~kg}^{-1}$ of silt, $386 \mathrm{~g} \mathrm{~kg}^{-1}$ of fine sand and $405 \mathrm{~g} \mathrm{~kg}^{-1}$ of coarse sand.

The tomato type "persimmon" of the company Topseed, a dominant F1 hybrid, which presents indeterminate growth habit, was used. The seeds were sowed manually in 128-cell polystyrene trays, on July 15, 2011 and July 17, 2012. The seedlings were transplanted to the field, with spacing of $0.5 \mathrm{~m}$ between plants and $1.0 \mathrm{~m}$ between rows, 26 days after sowing. A water depth of $13.3 \mathrm{~mm}$ was applied after transplanting based on the Penman-Monteith (ETo) equation (Equation 01) (ALLEN et al., 1998) and on the coverage factor, so that the seedlings were established in the field through the acclimatization process. The effects of the different irrigation frequencies were assessed at twenty days after transplanting (DAT), when the plants were fully acclimated to the field.

A randomized block experimental design was used in the two crop cycles, with six irrigation frequencies, consisted of 2 (F2), 3 (F3), 4 (F4), 5 (F5), 6 (F6) and 7 (F7) days of interval between irrigations, and four replications.

A drip irrigation system with on-line drippers 
inserted into polyethylene tubes and flow of 4 liters per hour was used.

A deep plowing (approximately $30 \mathrm{~cm}$ ) followed by two cross harrowing was carried out in the area before the transplanting of tomato seedlings. Afterwards, the area was cleaned with a rake, aiming to remove cultural remains from the soil, which could affect the installation of the irrigation system or application of the treatments. The terrain was manually leveled and the plant rows $(20-\mathrm{cm}$-high and $30-\mathrm{cm}$-wide) were arranged to enable a greater deepening of the plant roots.

Soil fertilization consisted of applications of nitrogen (N) (urea) and of potassium $\left(\mathrm{K}_{2} \mathrm{O}\right)$ (potassium chloride). One third of the total nitrogen (urea) (11.11 g per hole) and total potassium (potassium chloride) (11.11 g per hole) was applied before planting, and two thirds of the $\mathrm{N}$ and $\mathrm{K}_{2} \mathrm{O}$ split in 11 applications, via fertigation, representing a total of $300 \mathrm{~kg} \mathrm{ha}^{-1}$ of $\mathrm{N}$ and $300 \mathrm{~kg} \mathrm{ha}^{-1}$ of $\mathrm{K}_{2} \mathrm{O}$, following the recommendations of the Campinas Agronomic Institute (RAIJ et al., 1997). Phosphorus (simple superphosphate) was applied in a single application (56 g per hole) before planting, representing $200 \mathrm{~kg} \mathrm{ha}{ }^{-1}$ of $\mathrm{P}_{2} \mathrm{O}_{5}$, following the recommendations of Alvarenga (2004).

The irrigation depth (Di) used was the same of the evapotranspiration estimated by the Penman-Monteith equation (Equation 01) (ALLEN et al., 1998), based on data obtained by a fully equipped automated meteorological station, installed near the experimental area.

$$
\text { ETo }=\frac{0.408 \Delta(\mathrm{Rn}-\mathrm{G})+\gamma \frac{900}{\mathrm{~T}+273} \mathrm{U}_{2}\left(\mathrm{e}_{\mathrm{s}}-\mathrm{e}_{\mathrm{a}}\right)}{\Delta+\gamma\left(1+0.34 \mathrm{U}_{2}\right)}
$$

in which ETo is the reference evapotranspiration $\left(\mathrm{mm} \mathrm{day}{ }^{-1}\right) ; S$ is the slope vapor pressure curve $\left(\mathrm{kPa}{ }^{\circ} \mathrm{C}^{-1}\right) ; \gamma$ is the psychometric coefficient $\left(\mathrm{kPa}^{\circ} \mathrm{C}^{-1}\right) ; R n$ is the radiation balance $\left(\mathrm{MJ} \mathrm{m}^{-2}\right.$ day $\left.^{-1}\right)$; $G$ is the heat flow in the soil $\left(\mathrm{MJ} \mathrm{m}^{-2}\right.$ day $\left.^{-1}\right) ; T$ is the daily average temperature $\left({ }^{\circ} \mathrm{C}\right) ; U_{2}$ is the wind speed

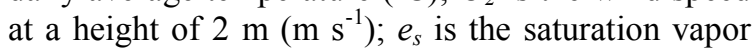
pressure $(\mathrm{kPa}) ; e_{a}$ is the partial vapor pressure $(\mathrm{kPa})$; and $\left(e_{s}-e_{a}\right)$ is the vapor pressure deficit.

The irrigation water management was based on the daily accumulated water depth, i.e., the total amount of water applied to each treatment was the same, but it was divided into applications of different amounts depending on the irrigation frequency of each treatment.

The time of irrigation for each treatment was calculated by the Equation 02 ,

$$
T i=\frac{L i \times E_{L} \times E_{g} \times F_{c}}{E i \times q_{g}}
$$

in which $\mathrm{Ti}$ is the time of irrigation (h); $\mathrm{Li}$ is the irrigation water depth to be applied $\left(\mathrm{mm} \mathrm{day}^{-1}\right) ; \mathrm{E}_{\mathrm{L}}$ is the spacing of the lateral lines $(1.0 \mathrm{~m}) ; \mathrm{E}_{\mathrm{G}}$ is the spacing of the drippers $(0.5 \mathrm{~m}) ; \mathrm{F}_{\mathrm{C}}$ is the coverage factor (dimensionless); Ei is the irrigation efficiency (dimensionless) (0.9); and $\mathrm{q}_{\mathrm{g}}$ is the drip flow $\left(4 \mathrm{~L} \mathrm{~h}^{-1}\right.$ )

The irrigation efficiency value was determined after the installation of the irrigation system in the field, using the methodology developed by Keller and Karmeli (1975).

The coverage factor $(\mathrm{Fc})$ used were 0.1 (20 to 25 DAT), 0.2 (26 to 31 DAT), 0.3 (32 to 37 DAT), 0.4 (38 to 43 DAT), 0.5 (44 to 49 DAT), 0.6 (49 to 54 DAT), 0.7 (55 to 59 DAT), 0.8 (60 to 65 DAT $), 0.9$ (66 to 71 DAT) and 1.0 (72 to 90 DAT, which is the stage of maximum water demand by the crop). These Fc were adapted from Dutra et al. (2000), following the criteria of intervals between each vegetative and reproductive stage of the tomato, comparing with the Fc of the melon crop in each vegetative and reproductive phase.

The accumulated precipitation in the period between irrigations was subtracted from the irrigation water depths to be applied, in order to ensure a correct irrigation water depth for each treatment and period.

The harvesting began at seventy DAT and ended at ninety DAT. The fruits were collected manually twice a week as their coloration changed, then, they were identified and placed in plastic bags, packed in boxes and taken to the Laboratory of the Agrometeorological Station of the UFC. The variables fruit diameter (FD), fruit length (FL), number of fruits per plant (NFP), fruit weight (FW) and fruit yield (FY) were evaluated.

The fruit length and diameter were measured with a digital caliper $(\mathrm{mm})$. The average fruit weight was measured in a semi-analytical balance, weighing each fruit individually. The total number of fruits of the evaluation area was counted. Fruit yield was estimated by multiplying the fruit weight per plant of each treatment by the planting density.

The prices of crop inputs were assessed in agricultural stores of Fortaleza CE, in September of 2011 and 2012, to carried out the economic analysis. The electricity cost was calculated based on the price of the $\mathrm{kW} \mathrm{h}^{-1}$ charged for rural properties. The prices paid for the $25-\mathrm{kg}$ box of table tomato, practiced in the State Food Supply Center (CEASA-CE) was also considered.

The data were subjected to analysis of variance by the $\mathrm{F}$ test and regression analysis. The models that presented high significance levels, coefficient of determination (R2) and biological significance were selected using the statistical program ASSISTAT. 


\section{RESULTS AND DISCUSSION}

The irrigation frequency affected $(\mathrm{p}<0.01)$ the fruit diameter (FD), fruit length (FL), fruit weight
(FW), number of fruits per plant (NFP) and fruit yield (FY) of tomatoes grown in the coastal region of the State of Ceará (CE), Brazil, during the crops season of 2011 and 2012 (Table 2).

Table 2. Analysis of variance of fruit diameter (FD), fruit length (FL), fruit weight (FW), number of fruits per plant (NFP) and fruit yield (FY) of tomatoes grown under different irrigation frequencies.

\begin{tabular}{lcccccc}
\hline & & \multicolumn{5}{c}{ Mean Square } \\
\cline { 3 - 6 } Source of & DF & \multicolumn{5}{c}{ August to December, 2011 } \\
\cline { 3 - 6 } Variation & & FD & FL & FW & NFP & YIELD \\
\cline { 3 - 6 } & 3 & $34.86^{* *}$ & $40.27^{* *}$ & $548.48^{* *}$ & $98.74^{* *}$ & $243.41^{* *}$ \\
\hline Treatment & 3 & $6.42^{\text {ns }}$ & $8.75^{\text {ns }}$ & $94.78^{\text {ns }}$ & $14.81^{\text {ns }}$ & $88.79^{* *}$ \\
Block & 3 & 6.52 & 106.07 & 13.38 & 12.79 \\
Residue & 9 & 6.21 & 6.23 & 16.18 & 19.55 \\
CV (\%) & - & 4.99 & \multicolumn{5}{c}{ August to December, 2012 } \\
\hline & & & $27.25^{*}$ & $552.16^{* *}$ & $222.86^{* *}$ & $492.69^{* *}$ \\
\hline Treatment & 3 & $75.83^{*}$ & $12.44^{\text {ns }}$ & $20.73^{\text {ns }}$ & $9.16^{\text {ns }}$ & $4.29^{\text {ns }}$ \\
Block & 3 & $6.90^{\text {ns }}$ & 9.06 & 83.01 & 19.33 & 7.71 \\
Residue & 9 & 23.51 & 7.09 & 15.70 & 15.38 & 8.73 \\
CV (\%) & - & 10.23 & & & \\
\hline
\end{tabular}

$\mathrm{FD}=$ Degrees of Freedom, $\mathrm{CV}=$ coefficient of variation; $* *=$ Significant at $1 \%$, $*$ Significant at $5 \%$; ns $=$ non- significant.

The effect of the irrigation frequency on the tomato fruit diameter is presented in Figure 1.

The irrigation frequency $\mathrm{F} 2$ resulted in the highest tomato FD, with 55.5 (2011) and $53.84 \mathrm{~mm}$
(2012), and the F7 resulted in the lowest FD, with

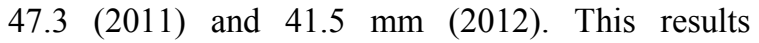
represent an increase in FD from F7 to F2 of $22.6 \%$ (2011) and 15.6\% (2012).

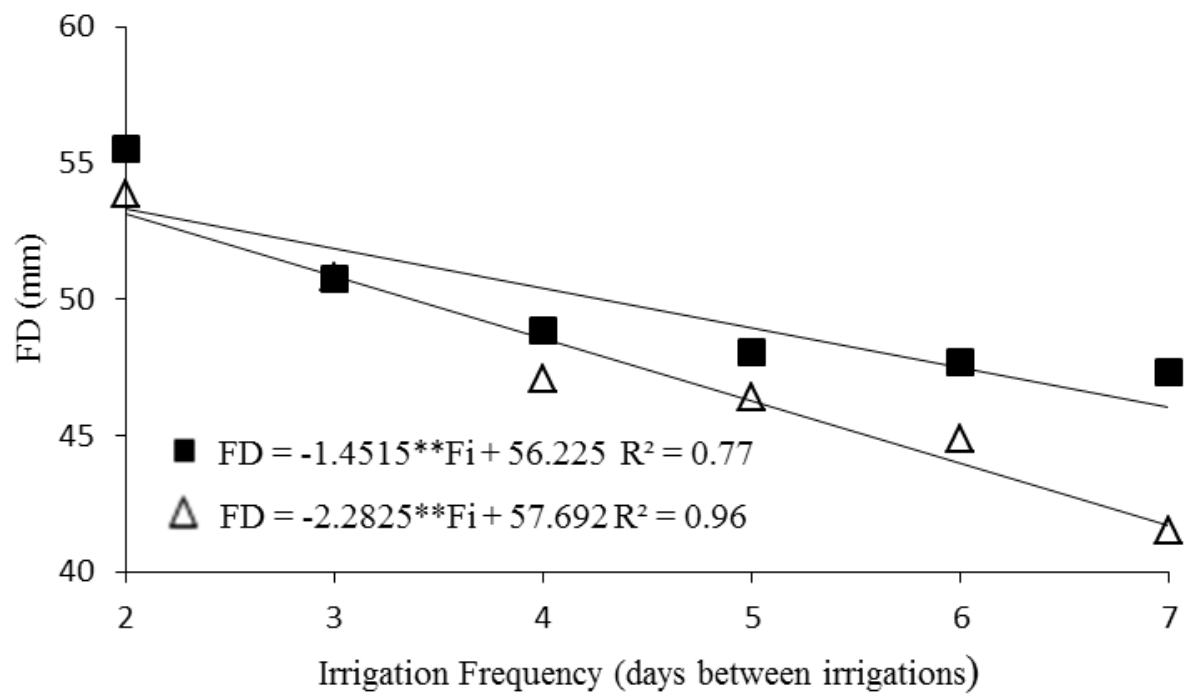

Figure 1. Fruit diameter (FD) of tomatoes as a function of irrigation frequency. Fortaleza, State of Ceará, Brazil. $\square=2011$; $\Delta=2012$.

Monte et al. (2009) grew tomatoes of the cultivar Débora (long-life) with irrigation frequency of two days and found higher fruit diameters to those found in the present work (above $60 \mathrm{~mm}$ ), however, they used a different cultivar and the plants were under different edaphoclimatic conditions.

Tomato fruits are classified according to their diameter. Fruits with diameter less than $40 \mathrm{~mm}$ are considered non-commercial. The FD found in the present work were above this minimum diameter required for commercial fruits, in both years (BRASIL, 1995).

The fruit length (Figure 2) of the tomatoes decreased linearly with reducing irrigation frequency. 


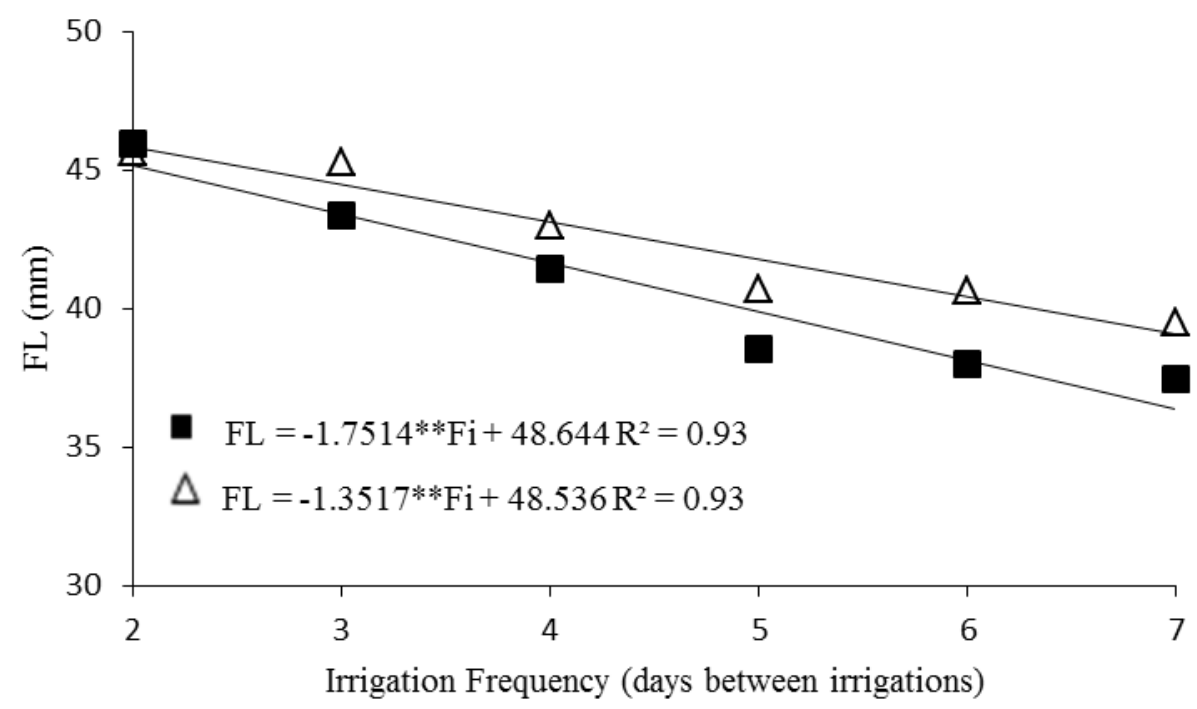

Figure 2. Fruit length (FL) of tomatoes as a function of irrigation frequency. Fortaleza, State of Ceará, Brazil. a = 2011; $\Delta=2012$.

The FL of the tomato fruits ranged from 37.44 to 45.91 (2011) and from 39.47 to $45.65 \mathrm{~mm}$ (2012). The reduction of the irrigation frequency reduced the length of the tomato fruits in both years. The FL of the tomato fruits were lower in 2011 than in 2012, which were probably because the precipitation was greater in 2011 than in 2012. The precipitation occurred in the period of fruiting and fruit growth of the first year (October 2011) may have stressed the plants by excess water, contributing to a lower FL, since climatic variations affect the quality and yield of vegetables (OLIVEIRA et al., 2011).

Moreover, according to Monte et al. (2013), tomato is sensitive to high temperatures, and plants subjected to temperatures above the ideal range reduce photosynthesis and increase mitochondrial respiration, which may decrease their carbon biomass (PIMENTEL, 1998). Santana et al. (2010) evaluated tomato crops under prolonged and severe water deficit and reported a reduced fruit growth. These results confirm those from other authors who evaluated tomato crops under water deficit and found negative effects on fruit quality and yield. (SOARES et al., 2011; SILVA et al., 2013).

The fruit weight (FW) of the tomatoes presented similar response to those for fruit diameter and length (Figure 3).

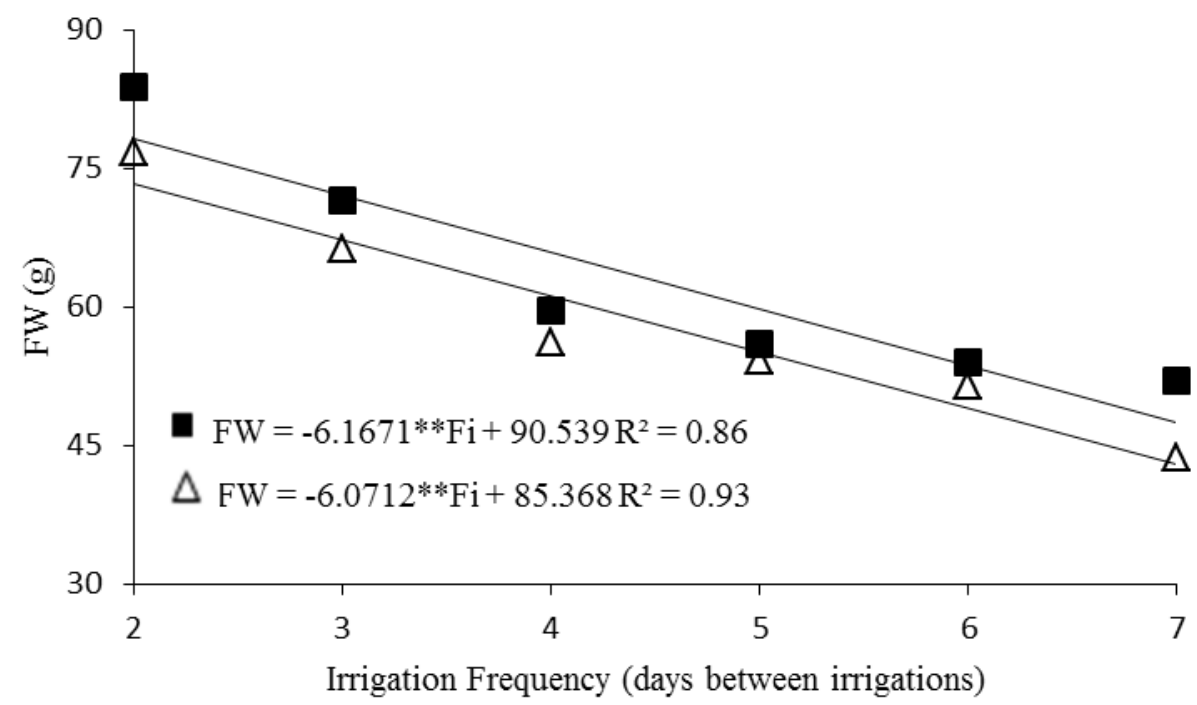

Figure 3. Fruit weight $(\mathrm{FW})$ of tomatoes as a function of irrigation frequency. Fortaleza, State of Ceará, Brazil. $\mathbf{\square}=2011$; $\Delta=2012$. 
The FW data fitted to a negative linear model. The plants under the highest irrigation frequency (F2) presented FW of $61.34 \%$ (2011) and 76.1\% (2012), which were higher than those under the lower irrigation frequency (F7). The highest (83.8 g) and lowest $(51.6 \mathrm{~g}) \mathrm{FW}$ were found in 2011 in the treatments F2 and F7, respectively. The treatments presented similar results in 2012, with highest FW of $76.4 \mathrm{~g}$ (F2) and lowest FW of $43.8 \mathrm{~g} \mathrm{(F7).}$

Madrid et al. (2009) assessed the effects of organic fertilization and irrigation rates on tomato crops and reported that the water deficit reduces leaf area and affects photosynthesis and water accumulation by the fruits and consequently, the fruit weight. Other authors also evaluated irrigation management in tomato crops and found responses of $\mathrm{FW}$, with decreasing irrigation frequency, similar to those found in the present work (KOETZ et al., 2010; SILVA et al., 2013).

It can be observed (Figure 4) the fruit yield (FY) of tomato presented a negative linear response to the reducing irrigation frequency in both years evaluated (2011 and 2012).

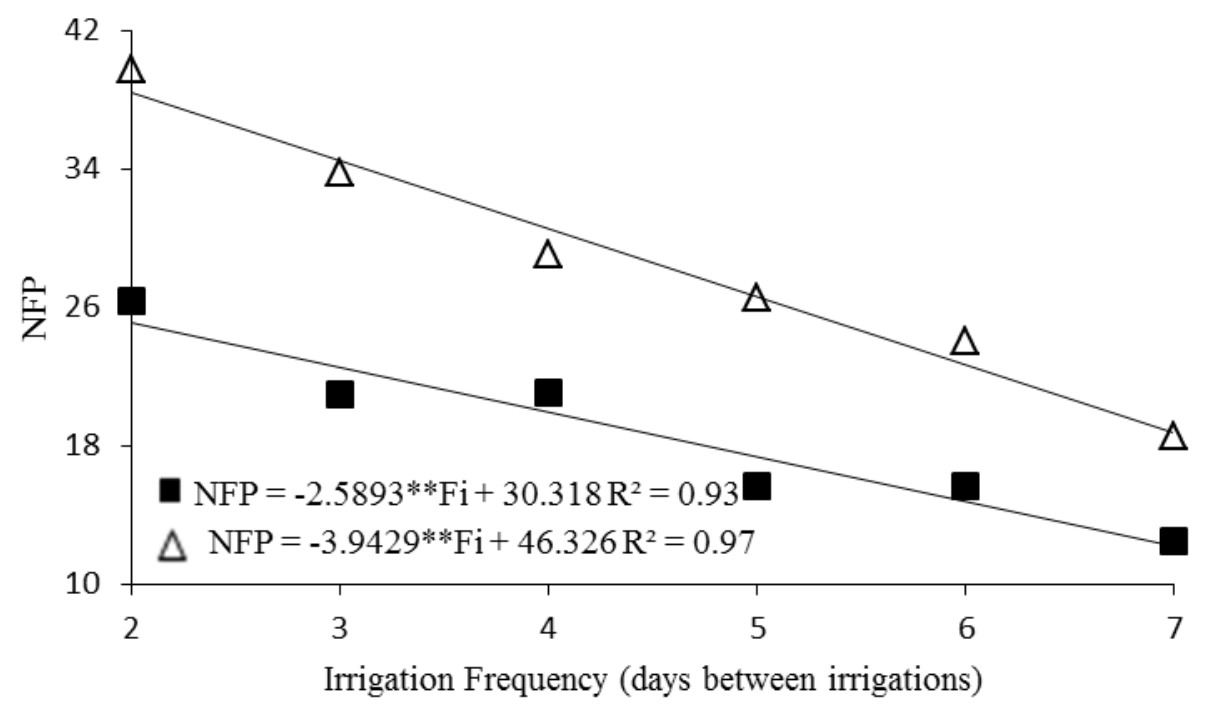

Figure 4. Number of fruits per plant (NFP) of tomatoes as a function of irrigation frequency. Fortaleza, State of Ceará, Brazil. $\mathbf{\square}=2011 ; \Delta=2012$.

Pires et al. (2009), evaluated different irrigation frequencies in tomato crops and also observed a reduction in NFP with decreasing irrigation frequency, as well as other authors, who observed the same trend (SILVA et al., 2013; OZBAHCE; TARI, 2010).

The precipitation occurred during the first year (August 2011) may have contributed to a greater flowering, since more frequent irrigations are recommended to plants during flowering and fruiting (NAIKA et al., 2006). Moreover, according to Marouelli and Silva (2005), the best performance of tomato is achieved with irrigations performed every two days.

The water stress, combined with an inadequate irrigation management and low initial soil moisture may cause abortion of flowers and fall of flower buds, thus reducing the number of fruits in the plant (GUANG-CHENG et al., 2008; PATANÈ, COSENTINO, 2010).

The fruit yield (FY) of tomato presented a negative linear response to the reducing irrigation frequency in both years evaluated (2011 and 2012)
(Figure 5)

The maximum yield found was 32.54 (2011) and 46.43 (2012) $\mathrm{Mg} \mathrm{ha}^{-1}$, both from plants under the highest irrigation frequency (F2).

The crops of 2012 presented higher yields than those in 2011, which may be related to the different precipitation in these years. The precipitation during the first experiment (2011) was $88 \mathrm{~mm}$, which may have increased the leaching of nutrients, while during the second experiment (2012), the precipitations were $4.6 \mathrm{~mm}$.

The excessive water is a limiting factor to high yields (PATANÈ, CONSENTINO, 2010), as confirmed by Kramer and Boyer (1995), who report that the more the crop is sensitive to the water deficit, the greater is the yield reduction.

The net income found in a simplified economic analysis as a function of irrigation frequencies, showed that the crops under treatment F2 (90 DAT) presented the highest economic returns for the producer in both years, with a positive net income of $\mathrm{R} \$ 8,977.58$ (2011) and $\mathrm{R} \$ 19,007.18$ (2012) (Figure 6). 


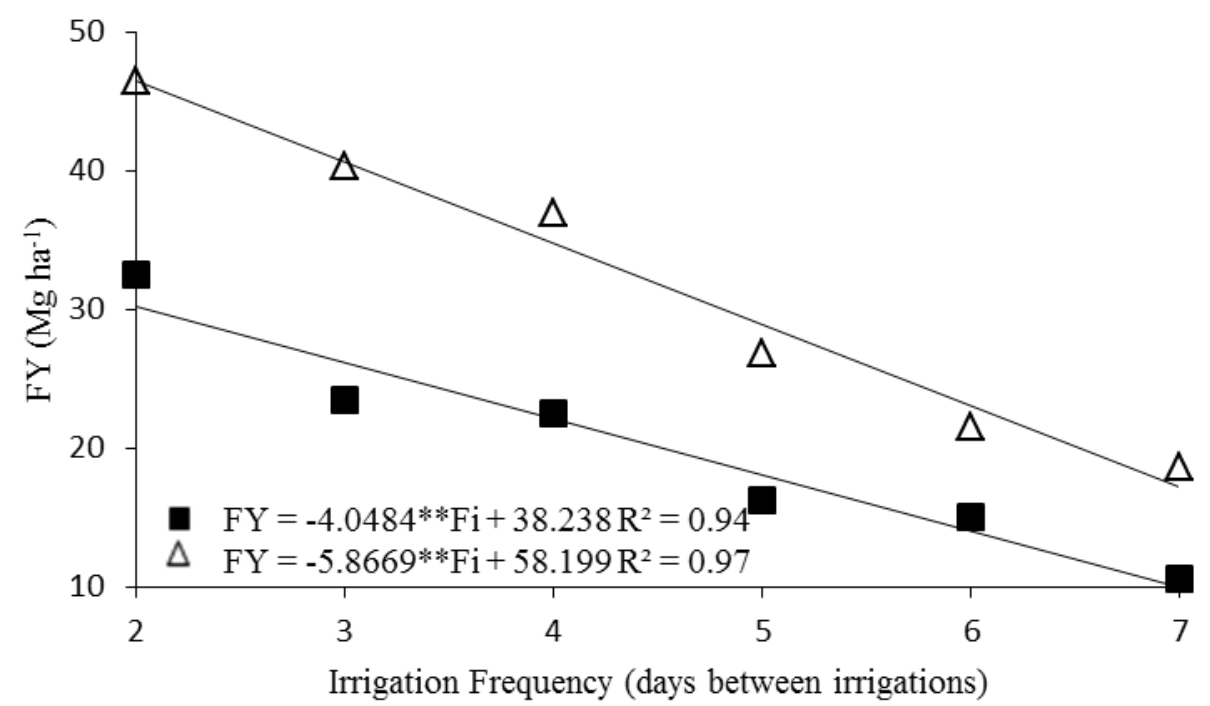

Figure 5. Fruit yield (FY) of tomatoes as a function of irrigation frequency. Fortaleza, State of Ceará, Brazil. a = 2011; $\Delta=2012$.

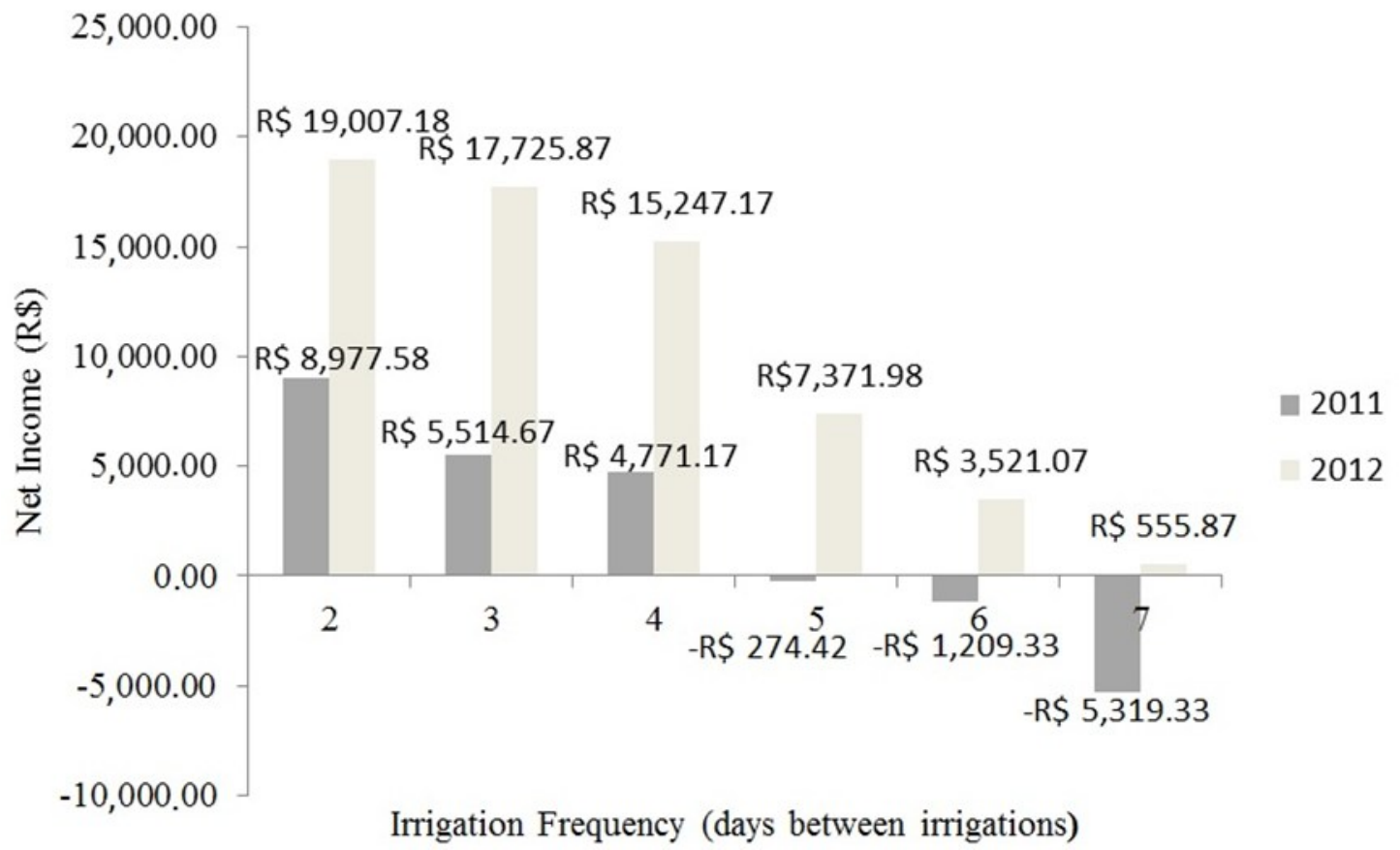

Figure 6. Net income (R\$) obtained with tomato crops as a function of irrigation frequency. Fortaleza, Ceará, 2011 and 2012.

On the other hand, treatments with irrigation intervals greater than four days presented losses in 2011.

The higher income obtained with the crops in 2012, compared with those in 2011, were due to the higher yields of 2012 .

Monte et al. (2009) evaluated irrigation frequencies in tomato crops and reported that the two-day irrigation interval results in plants with the same fruit quality than those under most frequent irrigations, but with greater water savings. Therefore, this is the recommended irrigation frequency for tomato producers.

According to Lima et al. (2012), economic analysis and reduction in water consumption are the basic factors to increase profit for tomato producers and promote water and energy savings in tomato crops. Thus, the irrigation frequency F2 (2-day interval between irrigations) was the best irrigation management for the tomato crops in both years and conditions evaluated.

\section{CONCLUSION}

The irrigation frequency F2 (2-day interval between irrigations) promotes better productive performance of field crops of tomato in the soil and climate conditions of Fortaleza, Ceará, Brazil.

Tomato producers of the coastal region of the 
State of Ceará, who aim to increase economic return, i.e., net income, must adopt a two-day irrigation frequency (F2).

\section{REFERENCES}

ALLEN, R. G. et al. Crop evapotranspiration: guidelines for computing crop water requirements. Roma: FAO, 1998. 328 p. (Irrigation and Drainage Paper, 56).

ALVARENGA, M. A. R. Tomate: Produção em campo, em casa-de-vegetação e em hidroponia. 1 . ed. Lavras, MG: UFLA, 2004. 400 p.

BERNARDO, S.; SOARES, A. A.; MANTOVANI, E. C. Manual de irrigação. 8. ed. Viçosa, MG: UFV, 2009. 625 p.

BRASIL. Ministério da Agricultura do Abastecimento e da Reforma Agrária. Portaria n553 de 30 de agosto de 1995. Diário Oficial da República Federativa do Brasil. Brasília: Imprensa Oficial. 1995. p. 25.

CARVALHO, J. A. et al. Análise produtiva e econômica do pimentão-vermelho irrigado com diferentes lâminas, cultivado em ambiente protegido. Revista Brasileira de Engenharia Agrícola e Ambiental, Campina Grande, v. 15, n. 6, p. 569-574, 2011.

DUTRA, I. et al. Determinação do fator de cobertura do melão cultivado sob diferentes lâminas e salinidades da água de irrigação. Revista Brasileira de Engenharia Agrícola e Ambiental, Campina Grande, v. 4, n. 2, p. 146-151, 2000.

EMPRESA BRASILEIRA DE PESQUISA AGROPECUÁRIA - EMBRAPA. Sistema brasileiro de classificação de solos. 2. ed. Rio de Janeiro, RJ: Embrapa Solos, 2006. 306 p.

FAGAN, E. B. et al. Eficiência do uso de água do meloeiro hidropônico. Bioscience Journal, Uberlandia, v. 25, n. 2, p. 37-45, 2009.

GUANG-CHENG, S. et al. Comparative effects of deficit irrigation (DI) and partial root zone drying (PRD) on soil water distribution, water use, growth and yield in greenhouse grown hot pepper. Scientia Horticulturae, Amsterdam, v. 119, n. 1, p. 11-16, 2008.

HIGUTI, A. R. O. et al. Produção de tomate em função da "vibração" das plantas. Bragantia, Campinas, v. 69, n. 1, p. 87- 92, 2010.
ESTATÍSTICA - IBGE. Sistema IBGE de recuperação automática - SIDRA. Disponível em: $<$ http://www.ibge.gov.br/home/estatistica/ indicadores/agropecuaria/lspa/lspa_201203.pdf>. Acesso em: 8 Jul. 2013.

KELLER, J.; KARMELI, D. Trickle irrigation design. Rain Bird Sprinkler Manufacturing Corporation, 1975. $133 \mathrm{p}$.

KOETZ, M. et al. Caracterização agronômica e ${ }^{\circ}$ brix em frutos de tomate industrial sob irrigação por gotejamento no sudoeste de Goiás. Revista Brasileira de Agricultura Irrigada, Fortaleza, v. 4. n. 1, p. 14-22, 2010.

KRAMER, P. J.; BOYER, J. S. Water relations of plants and soils. San Diego: Academic Press, 1995, $495 \mathrm{p}$.

MADRID, R. et al. Effects of organic fertilizers and irrigation level on physical and chemical quality of industrial tomato fruit (cv. Nautilus). Journal of the Science of Food and Agriculture, Oxford, v. 89, n. 15 , p. 2608-2615, 2009

MAROUELLI, W. A.; SILVA, W. L. C. Frequência de irrigação por gotejamento durante o estádio vegetativo do tomateiro para processamento industrial. Pesquisa Agropecuária Brasileira, Brasília, v. 40, n. 7, p. 661-666, 2005.

MAROUELLI, W. A.; SILVA, W. L. C.; SILVA, H. R. Irrigação por aspersão em hortaliças: qualidade da água, aspectos do sistema e método prático de manejo. 2. ed. Brasília, DF: Embrapa Informação Tecnológica, 2008. 150 p.

MONTE, J. A. et al. Influência do turno de rega no crescimento e produção do tomateiro no verão em Seropédica. Horticultura Brasileira, Brasília, v. 27, n. 2, p. 222-227, 2009.

MONTE, J. A. et al. Growth analysis and yield of tomato crop under different irrigation depths. Revista Brasileira de Engenharia Agrícola e Ambiental, Campina Grande, v. 17, n. 9, p. 926-931, 2013.

NAIKA, S. et al. A cultura do tomate, produção, processamento e comercialização. 1. ed. Wageningen, Países Baixos: DIGIGRAFI, 2006. 104 p.

LIMA, E. M. C. et al. Produção de pimentão cultivado em ambiente protegido e submetido a diferentes lâminas de irrigação. Revista Agrotecnologia, Anápolis, v. 3, n. 1, p. 40-56, 2012.

LIMA JÚNIOR, J. A. et al. Avaliação econômica da 
produção de alface americana em função de lâminas de irrigação. Engenharia Agrícola, Jaboticabal, v. 35, n. 2, p. 392-398, 2011.

OLIVEIRA, E. C. et al. Viabilidade técnica e econômica da produção de ervilha (pisum sativum 1.) cultivada sob diferentes lâminas de irrigação. Engenharia Agrícola, Jaboticabal, v. 31, n. 2, p. 324-333. 2011.

OZBAHCE, A.; TARI, A. F. Effects of different emitter space and water stress on yield and quality of processing tomato under semiarid climate conditions. Agricultural Water Management, Turkey v. 97, n. 9, p. 1405-1410, 2010.

PATANÈ, C.; COSENTINO, S. L. Effects of soil water deficit on yield and quality of processing tomato under a Mediterranean climate. Agricultural Water Management, Amsterdam, v. 97, n. 1, p. 131-138, 2010.

PIMENTEL, C. Metabolismo do carbono na agricultura tropical. 1. ed. Seropédica, RJ: EDUR, 1998. $150 \mathrm{p}$.

PIRES, R. C. M. et al. Desenvolvimento e produtividade do tomateiro sob diferentes frequências de irrigação em estufa. Horticultura Brasileira, Brasília, v. 27, n. 2, p. 228-234, 2009.

RAIJ, B. V. et al. Recomendações de adubação e calagem para o Estado de São Paulo. 2. ed. Campinas: IAC, 1997. 285p. (Boletim Técnico, 100).

RONCHI, C. P. et al. Manejo de plantas daninhas na cultura do tomateiro. Planta Daninha, Viçosa, v. 28, n. 1, p. $215-228,2010$.

SANTANA, M. J. et al. Resposta do tomateiro irrigado a níveis de reposição de água no solo. Revista Irriga, Botucatu, v. 15, n. 4, p. 443-454, 2010.

SANTANA, M. J.; VIEIRA, T. A.; BARRETO, A. C. Efeito dos níveis de reposição de água no solo na produtividade do tomateiro. Horticultura Brasileira, Brasília, v. 27, n. 2, p. 1378-1384, 2009.

SEPASKHAH, A. R.; AHMADI, S. H. A review on partial root-zone drying irrigation. International Journal of Plant Production, Gorgan, v. 4, n. 4, p. 1735-8043, 2010.

SILVA, J. A. S. et al. Aspectos agronômicos do tomateiro "Caline Ipa 6" cultivado sob regimes hídricos em área do semiárido. Revista Agro@mbiente On-line, Boa Vista, v. 8, n. 3, p. 336-344, 2014.
SILVA, J. M. et al. Cultivo do tomateiro em ambiente protegido sob diferentes taxas de reposição da evapotranspiração. Revista Brasileira de Engenharia Agrícola e Ambiental, Campina Grande, v. 17, n. 1, p. 40-46, 2013.

SOARES, L. A. A. et al. Crescimento do tomateiro e qualidade física dos frutos sob estresse hídrico em ambiente protegido. Revista Verde, Pombal, v. 6, n. 3, p. 203-212, 2011. 